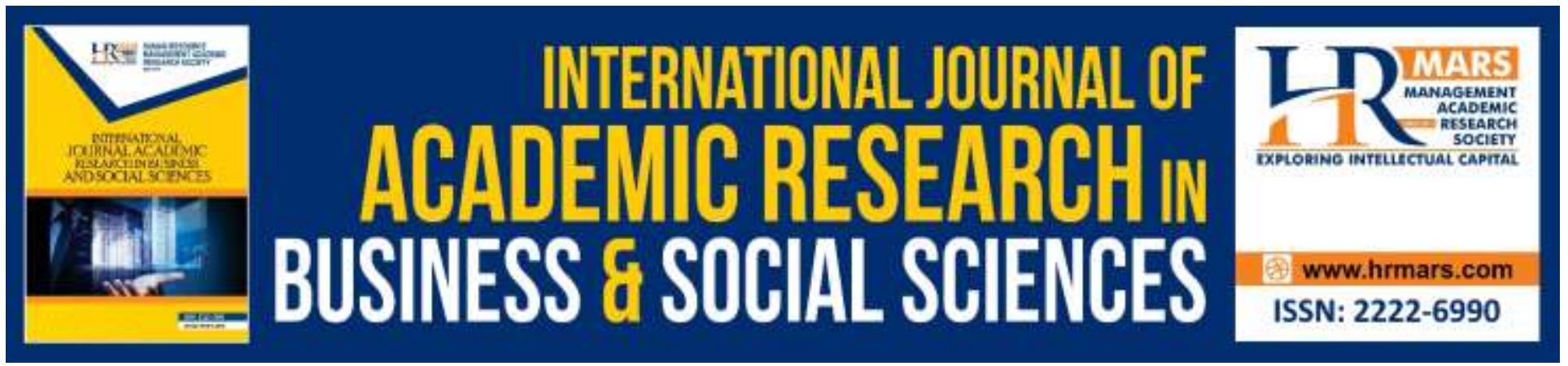

\title{
A Global View towards Understanding of Standard and Non- Standard Varieties of English
}

\author{
Hamzah Faleh Migdadi, Kamariah Yunus, Abdul-Fattah Al.Garni
}

To Link this Article: http://dx.doi.org/10.6007/IJARBSS/v10-i2/6894

DOI:10.6007/IJARBSS/v10-i2/6894

Received: 21 December 2019, Revised: 11 January 2020, Accepted: 29 January 2020

Published Online: 03 February 2020

In-Text Citation: (Migdadi et al., 2020)

To Cite this Article: Migdadi, H. F., Yunus, K., \& Al.Garni, A.-F. (2020). A Global View towards Understanding of Standard and Non-Standard Varieties of English. International Journal of Academic Research in Business and Social Sciences, 10(2), 103-115.

Copyright: (c) 2020 The Author(s)

Published by Human Resource Management Academic Research Society (www.hrmars.com)

This article is published under the Creative Commons Attribution (CC BY 4.0) license. Anyone may reproduce, distribute, translate and create derivative works of this article (for both commercial and non-commercial purposes), subject to full attribution to the original publication and authors. The full terms of this license may be seen at: $\underline{\text { http://creativecommons.org/licences/by/4.0/legalcode }}$

Vol. 10, No. 2, 2020, Pg. 103 - 115

http://hrmars.com/index.php/pages/detail/IJARBSS

JOURNAL HOMEPAGE

Full Terms \& Conditions of access and use can be found at http://hrmars.com/index.php/pages/detail/publication-ethics 


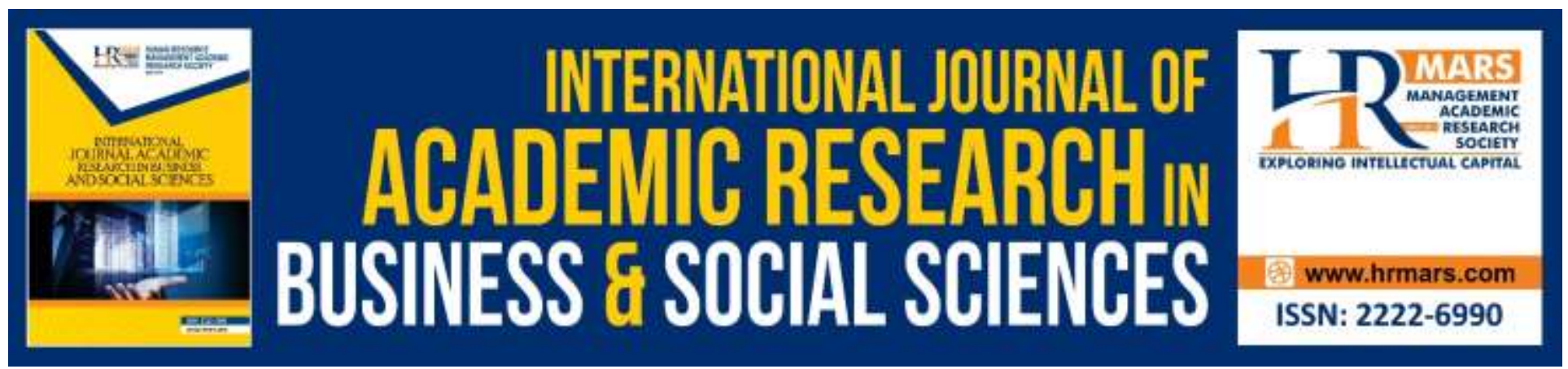

\title{
A Global View towards Understanding of Standard and Non-Standard Varieties of English
}

\author{
Hamzah Faleh Migdadi ${ }^{1}$, Kamariah Yunus ${ }^{2}$, Abdul-Fattah Al.Garni ${ }^{3}$ \\ ${ }^{1+2}$ Universiti Sultan Zainal Abidin, Faculty of Languages and Communication \\ ${ }^{3}$ Jubail Industrial College, English Language Institute \\ Email: hamzahmigdady@yahoo.com
}

\begin{abstract}
English is the most successful recognized global language. However, sociolinguists have a sheer of divergent views on the complexity of the present-day world English varieties in terms of standardization. There is little explicit agreement about exactly how Standard English ought to be viewed. It is a common belief among those who work with English that it exists. However, the portrayals made of it in various linguistic works, dictionaries and grammar books show how much diversity there is in individuals' thoughts regarding Standard English. The questions of what constitute a variety of English characterized as Standard or good English is still an area of dispute among the sociolinguists. This paper aims to examine the perspectives and challenges on the classification of English as standard and non-standard varieties in terms of lexicon in use. It identifies how words are accepted as common, colloquial and academic or formal. With the sheer of practical discussion and couple of examples the paper contributes a great deal towards understanding of Standard English and Non-standard varieties.
\end{abstract}

Keywords: Colloquial English, Common English, English Varieties, Standard English, non-standard English, Global Language, Slangs

\section{Introduction}

The study of "varieties of English around the world", the "New Englishes" or "World Englishes" appeared at the intersection of dialectology, sociolinguistics and historical linguistics in the early 1980 s and has been among the most vibrant sub-fields of English linguistics in recent years (Mair, 2016b). The universal dominance of the English language has reinforced the importance of teaching and learning it as either official second language or foreign language all over the countries in the world. In addition, the globalization raises the need for an international language and English seems to hold this status (Crystal, 2012). Thus, English is unanimously accepted as the global language by international consensus (Filppula, Klemola, Mauranen, \& Vetchinnikova, 2017; Triantafyllia \& Katerina, 2015). The researchers in the field of language planning and language policy confirm that English is used in 105 countries (Ethnologue, 2005) and also has a special status in more than 70 
INTERNATIONAL JOURNAL OF ACADEMIC RESEARCH IN BUSINESS AND SOCIAL SCIENCES Vol. 10, No. 2, Feb, 2020, E-ISSN: 2222-6990 @ 2020 HRMARS

countries (McKay, 2002) with foreign speakers outnumber those who speak it as mother tongue estimated (Graddol, 2006; Canagarajah, 2006; \& Crystal, 2012; Pragasam, Singh, Singh, Mostafa, Ja'afar, Abdullah, Khaja, 2018). As a result, many countries all over the world have recognized a special status for English. English is learnt as a global language all through the whole traverse of the school a very long time from Kindergarten to the second optional review, and it is considered as a mandatory subject for the school educational modules. English language received a high recognition as the international lingua franca, and used for varieties of purposes, social advancement, procurement of new innovation, and training (Zughoul, Abdul-Fattah 2003).

Moreover, Crystal (2012) notices that many publications and headlines in the news emerged since early eighties discussion about the current status of English in the world have neglected to give firm predictions about the future of English in the world, as he construes that the momentum of growth of English amidst the other languages in the globe "has become so great that there is nothing likely to stop its continued spread as a global lingua franca, at least in the foreseeable future" (p.1). Henceforth, there is a strong interest in maintaining certain standards of correctness through features of accent and grammatical forms of English. These features are often equated with the standard language. Linguists who attempt to resist the ideological underpinnings have been hampered by a set of research paradigms that have dominated linguistic study certainly during this century and in varying forms in the preceding centuries (Mair, 2014; Desfitrina, 2018). This paper aims to give an overviews of English standard and non-standard from the global perspectives.

\section{World Englishes}

According to Saltzman (2017), the history of World Englishes is bound up with a history of colonialism and imperialism, oppression and hegemony. We cannot ignore the fact that, where English has arisen as a second or official language in the so-called outer circle, it has arisen often in direct connection to periods of colonial rule. Where English pidgins and creoles have developed, they have done so often in the context of slavery and subjugation. And where English becomes a dominant language, vernacular languages and the cultural heritage of which they are an integral part are often at risk of being wiped out. In many areas of the world, however, creoles and Englishes also become a site of local identity in their own right, used as a medium for empowerment and sooner or later for literary creativity.

Moreover, the term 'world Englishes' is capable of a range of meanings and interpretations. In the first sense, perhaps, the term is used as an umbrella label referring to a various approaches to the description and analysis of world Englishes. Some scholars employ other terms such as 'global English' (Crystal, 2012) and 'international English' (Bolton, 2006). These terms are utilized for the variety of Englishes around the world. Millions of people use English everywhere and every day. Presently, English is the dominant language used for air-traffic control, most of academic conferences, technology, diplomacy, sports and international business (Melchers \& Shaw, 2013). The English language is now spoken in more than 100 countries (Bolton, 2006). World Englishes' Varieties comprise, for example, American English, Australian English, British English, Canadian English, Caribbean English, Chicano English, Chinese English, Euro-English, Indian English, New Zealand English, Nigerian English, Scottish English, Singapore English, South African English, West African 
INTERNATIONAL JOURNAL OF ACADEMIC RESEARCH IN BUSINESS AND SOCIAL SCIENCES Vol. 10, No. 2, Feb, 2020, E-ISSN: 2222-6990 @ 2020 HRMARS

Pidgin English ...etc. World English according to McArthur (2004, P. 5) "is both shorthand for English as a world language and a superordinate term for Australian English, British English, Irish English, Nigerian English, and the like. It embraces all aspects of the language: dialect, pidgin, creole, variety, standard, speech, writing, paper-based, electronic"

Kachru (1992) has classified the use of English in the world into three major circles. The inner circle includes nations in which English is the native language; the external circle includes nations in which English is a second language; and the expanding circle includes nations in which English is a distant or a foreign language. To elucidate, Kachru's first circle refers to places where English is first language including United States of America, Great Britain and Australia. While the second circle, includes the speakers of English as a Second Language (ESL). These are to be found in those countries where English is utilized as an official language, or potentially as a language of instruction. The latest circle includes speakers of English as a Foreign Language (EFL) who learn English as a means of universal correspondence. As illustrated in the figure below:

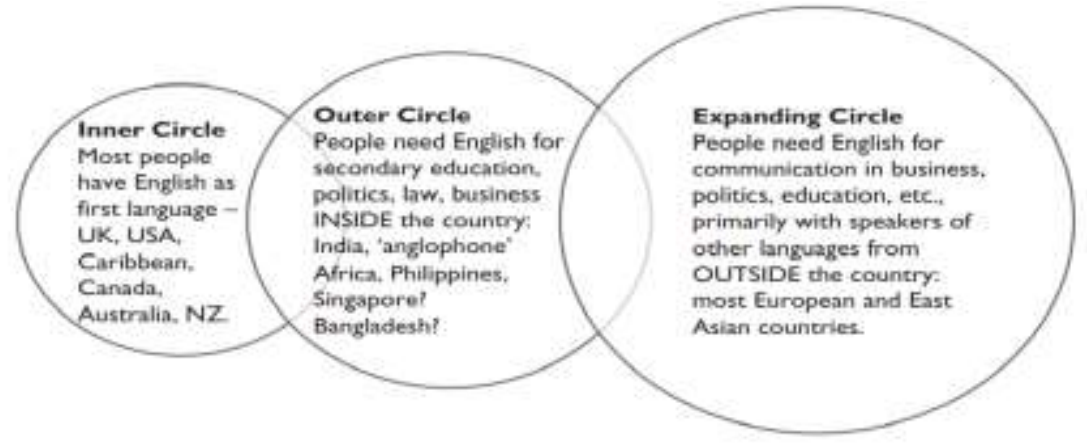

Figure 2: Kachru's circles model

Kachru's (1992) first circle refers to places where English is first language including United States of America, Great Britain and Austria. While the second circle, includes the speakers of English as a Second Language (ESL). These are to be found in those countries where English is utilized as an official language, or potentially as a language of instruction and additionally as a method for more extensive correspondence inside the nation by individuals who are not local speakers. There are numerous such nations on the planet English is a language which has more non-native speakers than native speakers. The last circle includes speakers of English as a Foreign Language (EFL) who learn English as a vehicle of universal correspondence. Individuals in Germany, Japan, Brazil and Morocco who have learnt English will typically hope to utilize it in connection with individuals from nations other than their own (Trudgill, \& Hannah, 2017).

\section{English as a Global Language}

According to Crystal (2012) a language can acquire a global status when it develops a special role that is recognized in every country. He argues that global status is not measured by having a large number of people speaking it as a mother tongue, but to achieve such a status, a language has to be spread over to other countries around the world where it received a special place within their communities, even. This can be achieved in two ways, firstly, a language can be made the official language of a country, to be used as a medium of communication in such domains as government, the law courts, 
the media, and the educational system. To get on in these societies, it is essential to master the official language as early in life as possible. Such a language is often described as a 'second language', because it is seen as a complement to a person's mother tongue, or 'first language'. The role of an official language is today best portrayed by English, which now has some kind of special status in over seventy countries, such as Ghana, Nigeria, India, Singapore and Vanuatu (Mair, 2016a).

Secondly, a language can be prioritized in a country's foreign-language teaching, without having official status. It becomes the most available foreign language which children are most likely to be taught when they arrive in school. This might be because of economic and military power. Through this means Latin became an international language during the Roman Empire not because Roman were numerous than the peoples they dominated but for the mighty of their military. Crystal (2012, p. 9) construes "a language has traditionally become an international language for one chief reason: the power of its people - especially their political and military power". Latin became an international language throughout the Roman Empire, but this was not because the Romans were more numerous than the peoples they subjugated. Therefore, there is the closest of links between language dominance and economic, technological, and cultural power, and this relationship will become ever clearer as in the case of English. Without a strong power-base, of whatever kind, no language can make progress as an international medium of communication (Crystal, 2012).

\section{Why Identifying Standard and Non-standard English Lexical Varieties is Important for Second Language Researchers and Learners?}

The rise of English to its present position of the world's undisputed lingua franca and the role of Global English in a multilingual world are core topics of World Englishes research (Mair, 2014). Identifying and categorising academic and non-academic lexical varieties is important for EFL researcher, learners, teachers, and material designers. For researchers identifying non-standard variety is important because there is lack of research on it and also they will be required to be consistent in using a particular variety when they are writing academically. And as result of wide used of social media and various means through which a language is acquired like watching movies and news those researchers may find it difficult to differentiate between varieties of English.

Another reason is closely related to features of English used by second language learners which is difficult to identify the variety they are using because of the context they were brought up and the reginal variety of English speak therein. There is tendency for those second language users of English to use particular variety peculiar to them while writing academically for the international audience like journal publication. For material designers, it is important for them to know different varieties of English usage in order to be consistent on a particular verities of English. However, certain reading materials might be based on a particular variety, let say British English or American English, the teachers and the context may be another ways through which the students acquire more vocabulary more often.

Another issue is that defining standard on itself is difficult because different models were devised by different scholars in deciding which variety is standard and which is not, like for example new Englishness like Malaysian English, Singaporean English Jamaican English in some extent they are all 
INTERNATIONAL JOURNAL OF ACADEMIC RESEARCH IN BUSINESS AND SOCIAL SCIENCES Vol. 10, No. 2, Feb, 2020, E-ISSN: 2222-6990 @ 2020 HRMARS

called variety of English on themselves as Mair (2016a), distinguishes between Standard Jamaican English and Jamaican Creole and between standard Nigerian English and Pidgin. However, it is important for those students majoring in English to know such variations.

\section{Standard vs. Non-standard English}

Wording here fundamentally takes after dialectological rehearse, which verifiably accept a mutual idea of Standard English amongst readers and researchers. Numerous studies particular on corpusbased investigations of recent years have exhibited that 'the standard' is certifiably not a solid element and these experiences are not challenged here. As Anderwald (2009) posits that the term 'standard' is not a monolithic entity and these insights are not contested here. The questions of what constitute a variety of English characterised as Standard or good English is still an area of dispute among the language academy in both Great Britain and United states (Mair, 2017). Therefore, 'Standard English' is considerably much more than a mythical entity or chimera, which would dissolve if you look at it too hard, although its exact borders may be fluid. Native speakers' attention to what constitutes 'adequate' language system is reflected by the immense scope of distributions that arrangement with the subject, also the enormous number of word references dependably a blockbuster when another version is stamped.

Standard English also is not a well-defined concept in itself, its meaning varies according geographical location and social context while slang and other non-standard varieties of English are even harder to define. Another issue to consider in defining non-standard may be reductive according to Coleman (2014) to he refers to technical usage of particular profession or interest group groups jargon (register) usage that is geographical restricted on a sub-national level (dialect). Biber and Conrad (2009, p. 6) define register as "a variety of associated with a particular situation of use, including particular communicative purposes". This is usage that enjoys a temporary high profile in the media, informal language used within families (family language), and informal language characteristic of particular social classes (sociolects or social dialects) or informal that is used by a single individual (idiolect). The meaning of slang and colloquial their examples remain entirely dependent on the context (Coleman, 2014).

Slang is employed in conjunction with standard and other non-standard forms of the language: within a family setting. Coleman (2014) posits that there are samples of language variety that are refer to slang, standard colloquial and family language; in a particular language. In a professional setting we might here professional and general slag used alongside jargon and the standard language. For examples, a doctor might refer to ashcash 'the fee paid for signing a death certificate' which is a professional slang; bladdered 'drunk' which is general slang, and nephrology which is 'the branch of medicine that deals with the kidney' which is technical usage (register) or jargon. Biber and Conrad (2019) define register as a particular usage of lexical items in English for specific purposes. Words that are used in academic settings are called academic register; words that are frequently used in a one field of study such as business, law, and media are the register of those fields.

Standard English is used widely in most written texts such as official documents, books, newspapers, media, and many others (Mair, 2014). The use of Standard English variety is a kind of social 
INTERNATIONAL JOURNAL OF ACADEMIC RESEARCH IN BUSINESS AND SOCIAL SCIENCES Vol. 10, No. 2, Feb, 2020, E-ISSN: 2222-6990 @ 2020 HRMARS

convention with no deep thinking about its preferential use or superiority over other dialects or varieties (Crystal, 2012). In fact, people tend to use standard rather than other available varieties because it becomes standardized. Many linguists in this field have stated that Standard English shares its structural features with the other English varieties. There are very few grammatical differences. Standard English is used in writing and speech worldwide (Kerswill, 2006). In other words, people use it as a selected, codified and stabilized process (Trudgill \& Hannah, 2017). Standard English has not acquired its status by any conscious decision. In fact, it has developed gradually, with the upper classes naturally using it in writing and speaking till it becomes used by all members of that society. In addition, Standard English is indeed codified. It has a grammar that is described widely in books and is also taught at classrooms. There are English dictionaries that illustrate norms for spelling, pronunciation and definitions. As a result, this codification provides a uniform or stable form of Standard English. This situation grants an opportunity to use this uniform and stable form of English in different parts of the English-speaking world and has led to it becoming the medium of instruction.

On the other hand, Trudgill and Hannah (2017) identify several grammatical features that make Standard English distinguishable from non-standard English dialects. First, Standard English uses the same past tense for the auxiliary verb (to do) and the main verb (to do). It uses (did) form for both forms. On the other hand, non-standard English dialects distinguish between the two forms of verb. They use (did) as the past tense of the auxiliary and use (done) for the past tense of the main verb, for example, (You done it, did you?).

Second, Standard English does not have negative agreement, while non-standard English dialects have as these agreements. For example, it is acceptable in non-standard English to say I couldn't find none nowhere, but it is absolutely not acceptable in Standard English, and it is acceptable to say I couldn't find any anywhere. Third, Standard English follows an irregular means of producing reflexive pronouns. For instance, it uses possessive pronouns such as myself, yourself, or himself, etc., and others object pronouns such as him, them, and me, etc. Non-standard English dialects follow a regular way of producing possessive pronouns, so they might say for example, myself, yourself, hisself, ourselves, yourselves, theirselves.

Furthermore, Standard English uses different past forms of verb (be) based on singularity and plurality. It uses (I was...) in singularity and (We were...) in plurality. While non-standard English dialects use the same form for either singular or plural subjects as (I was...) and (We was...). Finally, Standard English uses different forms of irregular verbs based on the structure. It uses the verb (go) in different verb forms such as (I go to the mall every day), (I went to the mall yesterday) and (I have gone to the mall recently.), but non-standard English dialects do not make a distinction between the past and past participle tenses. So it is acceptable to say in non-standard English dialects (I have seen him) and (I could have went versus I seen him; I went).

There is a debate between two points of view about standard and non-standard speech. The former view generally considers non-standard English dialects as isolated deviations from Standard English but the other looks at them as isolated systems that have to be studied without reference to the Standard English. Based on the second view, researchers can understand the internal relations of a 
INTERNATIONAL JOURNAL OF ACADEMIC RESEARCH IN BUSINESS AND SOCIAL SCIENCES Vol. 10, No. 2, Feb, 2020, E-ISSN: 2222-6990 @ 2020 HRMARS

dialect's grammatical system. But the real problem in this field is that there are a few studies that comprehensively focus on the grammatical, morphological and also semantic aspects of nonstandard English dialects (Labov, 1969).

Hughes and Trudgill (1996) view dialects as varieties that have some differences between each other in vocabulary and grammar. For instance, the difference of the verb forms in the following examples (I wrote it.) and (I write it.), or using negation in different patterns such as (I don't want any) and (I don't want none). And also, people in parts of northern England use the verb (grave) for 'dig' (Trudgill, 1999). From a sociolinguistic perspective, Britain (2005) indicates that 'dialect' does not have a single definition but in reality it has a range of definitions. The 'Anglo-Saxon' world considers 'dialect' as any variety of language that can be described linguistically or (more rarely) socially. Thus, Standard English is a dialect. A description of it tends to go against most lay perceptions. According to Kerswill (2006) lay speakers and also many linguists look at a dialect as a branch of a language that is usually restricted geographically in its distribution. Britain (2005) points out that most definitions do not view dialects as standardized, and are hence more subject to variability. Towards the communicative function, some commentators state that non-standard dialects do not have 'communicative functionality' while others claim that the outside institutional contexts exercise a greater communicative function more than standard varieties (Ammon 1998, p.197, as cited in Kerswill, 2006).

\section{Oxford English Dictionary Classification of English Lexical Variation}

Another way of looking into words form lexis is the word in use. This is also refers to register approach lexicon based forms. Based on this classification words are classified into standard and non-standard lexical items. Looking at this from another angle, words in Oxford English Dictionary are categorised into central and the peripheral lexical items.

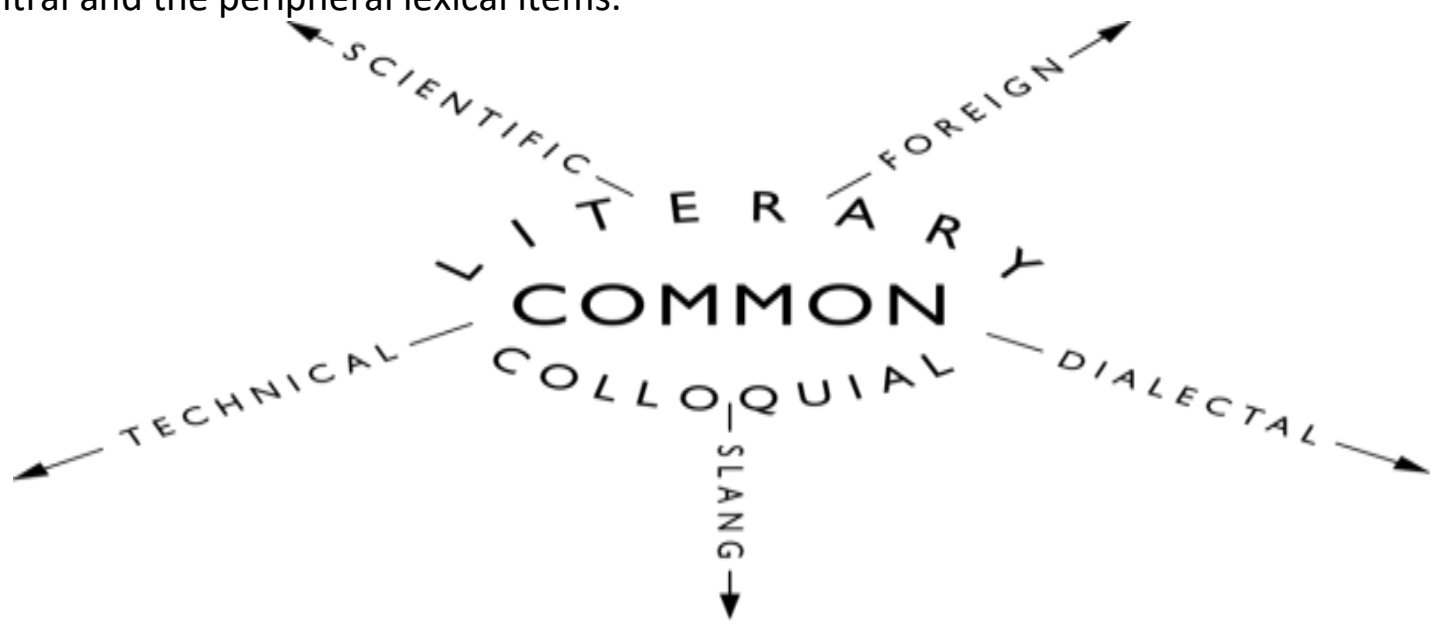

Figure 1: English Lexical Items according to The Shorter Oxford English Dictionary (SOED)

Common lexical items, are the at the central core of the English lexicon is occupied by lexical items that are common to all native speakers and are not specifically marked for any of the other categories. Literary English refers to written and formal vocabulary, the language of science and literature. 
Colloquial English comprises spoken and informal items. Archaic, foreign and scientific language belong in the formal part of lexis ('are the specially learned outposts of the literary language', SOED 2007, p. x), while dialectal, vulgar and slang vocabulary 'form a group of lower or less dignified status'. Moving in a clockwise direction, one can see how the terms on the periphery are related to one another. Archaic items, often met with in poetry, also survive in dialect, and both are outcrops of older strata of the language; dialect items, vulgarisms and slang share their informal character; vulgarisms and slang items are both sub-colloquial and can cause offence through their coarse nature; slang (as in public school slang, RAF slang) and technical both refer to specialized languages. The same applies to scientific; furthermore, the language of science is rich in foreign loans. The only exception is the pair foreign and archaic, where there is no link, pace the SOED, which is why we have put between the two a dividing line that is not found in the original diagram.

\section{Literary English: Scientific and foreign}

Literary English refers to written and formal vocabulary, the language of science and literature. A scientific English is also comprises register. Register is defined linguistically as a particular usage of lexical items in English for specific +purposes (Hyland, 2006). The particular style of the use of words and grammar in a certain field of study is called a register in that field (Benesch, 2001). Sociolinguists deal with language register as a particular manner of using a language among members of occupation groups for the purpose of achieving specific purposes.

\section{Common: Dialectal and Technical}

Common lexical items, are the at the central core of the English lexicon is occupied by lexical items that are common to all native speakers and are not specifically marked for any of the other categories.

\section{Colloquial English: Slang}

This is a form of language variation which is commonly used for casual communication purposes. The classification of lexical items as forms of colloquial language variety is based on the level of acceptance by the native speakers of language (Collins \& Yao, 2018). Moreover, the increasing acknowledgment of colloquial features particularly in more formal discourses has been an incredible linguistic change in English since the mid-twentieth century (Collins, 2013). Collins and Yao (2013) concentrated on the linguistic colloquialisation over a scope of registers in ten world Englishes including British English, American English, Australian English etcetera. The discoveries demonstrated that the ten Englishes examined showed diverse levels of everyday propensity. This recommends couples of conversational articulations have been acknowledged by formal registers, which gave some useful and demonstrative data for the accompanying investigations ( $\mathrm{Ni}, \&$ Wang, 2017).

\section{Slang}

Slang is a widespread phenomenon in English, but, despite its pervasiveness, it has been marginalized or neglected in linguistics (Mattiello, 2008). It is a form of language variation which is seen as a deviant of standard form of language. The classification of lexical items as forms of slang language variety is based on the level of acceptance by the native speakers of language (Partridge, 2015). Slang words and phrases, are rarely appear in the students' textbook. Mostly they acquired them through watching movies (Kabooha, 2016) or reading casual magazines or found them in their interaction in 
INTERNATIONAL JOURNAL OF ACADEMIC RESEARCH IN BUSINESS AND SOCIAL SCIENCES Vol. 10, No. 2, Feb, 2020, E-ISSN: 2222-6990 @ 2020 HRMARS

the various social media. Examples, of some slangs words are; Hamm means powerful, Wanna means want to, Gonna means want to go (Kundi, Ahmad, Khan, \& Asghar, 2014), kinda and sorta mean kind of and sort of. Slang and colloquial English varieties are context dependent (Coleman, 2014) there are British and American slangs. But this is not restricted to only American and English varieties of English but to all world Englishes. Some non-standard may be as a results of multi-cultural setting. For example, in United Kingdom police slang you may here words like 'ordinary decent criminals' referring to criminal you can find other colloquial terms referring to criminal by police in different context. As this study will be restricted to the particular slangs and colloquial English that are commonly used by Jordanian undergraduate students. Another source of slangs is hip-hop music (Coleman, 2014) people may be influenced by usage of particular lexical items or phrase by listening to Hip-Hop music, such as mother fucker, nigger, bebe etc.

In addition, slang as a non-standard variety represents informal speech. There is a tendency to identify slang as a language variety that is used commonly between members of groups of people who share different norms together. For example, the variety that is used in communication among army recruits is considered as slang. On the other hand, colloquialism is the variety that is used between groups of people who are socially related to each other, such as friends or relatives. Both slang and colloquialisms are informal speech that uses informal linguistic units in informal settings.

Slang is also a type of non-standard English that is a widespread phenomenon in English. For example, English people use the word HAMM to mean powerful, WANNA to refer to want to, and GONNA which means want to go (Kundi, Ahmed, Khan, \& Asghar 2014). In spite of slang's pervasiveness, it has been commonly neglected in the field of English learning. Slang words or phrases rarely appear in the students' text-books. Teachers rarely refer to them in the classrooms, either. However, there can be no denying that students of English use slang words while they speak or write in English. Thus, the assumption is that there are other ways to acquire slang or at least some slang words. Researchers have concluded that there are many channels through which learners of English acquire slang words or expressions. For example, they are mostly acquired through watching TV programs, English movies and songs (Kabooha, 2016). Moreover, they learn these non-standard English varieties through reading casual magazines, communicating with others face to face or through social media.

\section{Conclusion}

This overview of World Englishes demonstrates just how far the debates and discourses pertaining to classification of world Englishes. As is indicated above, there are currently a number of overlapping and intersecting approaches to this field of inquiry. What also emerges from this overview, however, is importance of learning this topic for second language learners, researchers and material designers. In this final section, we might now pause to consider the implications of such approaches for applied linguistics. Elsewhere, English acquisition especially in the expanding circle, but also in the outer circle becomes associated with global opportunities, bringing with it a perception of prestige and new possibilities for cross-cultural communication (Saltzman, 2017). There is no doubt that the required language in the academic setting is formal form of language.

Theoretically, this study offered sheer of issues related to English varieties including standard and non-standard. This paper contributed to the field of English varieties, particularly in non-standard 
INTERNATIONAL JOURNAL OF ACADEMIC RESEARCH IN BUSINESS AND SOCIAL SCIENCES Vol. 10, No. 2, Feb, 2020, E-ISSN: 2222-6990 @ 2020 HRMARS

English varieties, for example, slang, dialects and jargons. Above all, this study will benefit the beginner researchers in their interests in varieties of English. Moreover, it will help EFL and ESL students around the world as it will be a good reference for bilingual students. Furthermore, the study contributed to the new trends of viewing English as a global language.

\section{References}

Ammon, U. (1998). Measuring the broadness of dialectal speech. Sociolinguistica 12: 194-207.

Anderwald, L. (2009). The morphology of English dialects: Verb-formation in non-standard English, Cambridge University Press.

Benesch, S. (2001). Critical English for academic purposes: Theory, politics, and practice. Routledge.

Biber, D., \& Conrad, S. (2019). Register, genre, and style. Cambridge University Press.

Britain, D. (2005). Dialect and accent. In Ammon, Ulrich, Mattheier, Klaus and Trudgill, Peter (eds.) In Klaus Mattheier, Ulrich Ammon and Peter Trudgill (eds.) Sociolinguistics/Soziolinguistik. An international handbook of the science of language and society/Ein internationales Handbuch zur Wissenschaft von Sprache und Gesellschaft, 2 nd edn., Vol. 2. Berlin: Walter de Gruyter, 267-273.

Conrad, S., Biber, D., Daly, K., \& Packer, S. (2009). Real grammar: A corpus-based approach to English. Pearson/Longman.

Collins, P., \& Yao, X. (2018). Colloquialisation and the evolution of Australian English. English World-Wide, 39(3), 253-277.

Coleman, J. (Ed.). (2014). Global English slang: methodologies and perspectives. Routledge.

Bolton, K. (2006). World Englishes Today. The Handbook of World Englishes./Edited by Braj B. Kachru, Yamuna Kachru, and Cecil L. Nelson.-Oxford, UK, Carlton, Victoria, Australia: Blackwell Publ, 240-269.

Canagarajah, A. S. (2006). The Place of World Englishes in Composition: Pluralization Continued. National Council of Teachers of English, June 2006, 586-619.

Crystal, D. (2012). English as a global language. Cambridge university press.

Coleman, H. (2011). Allocating resources for English: The case of Indonesia's English medium international standard schools. Dreams and realities: Developing countries and the English language, 87-111.

Desfitrina (2018). The Influence, Gender, Life on Development Planning in Indonesia, International Journal of Academic Research in Accounting, Finance and Management Sciences 8 (3): 255264.

Ethnologue (2005). On WWW at http://www.ethnologue.com

Filppula, M., Klemola, J., Mauranen, A., \& Vetchinnikova, S. (Eds.). (2017). Changing English: global and local perspectives (Vol. 92). Walter de Gruyter GmbH \& Co KG.

Graddol, D. (2006). English Next. London: British Council.

Hughes A., Trudgill P. (1996). English accents and dialects. An introduction to social and regional varieties in English in the British Isles, London: Arnold.

Hyland, K. (2006). English for academic purposes: An advanced resource book. Routledge.

Kachru, B. B. (1992). Teaching World Englishes. The other tongue: English across cultures, 2(2), 355-365. 
INTERNATIONAL JOURNAL OF ACADEMIC RESEARCH IN BUSINESS AND SOCIAL SCIENCES

Vol. 10, No. 2, Feb, 2020, E-ISSN: 2222-6990 @ 2020 HRMARS

Kabooha, R. H. (2016). Using Movies in EFL Classrooms: A Study Conducted the English Language Institute (ELI), King Abdul-Aziz University. English Language Teaching, 9(3), 248.

Kundi, F. M., Ahmad, S., Khan, A., \& Asghar, M. Z. (2014). Detection and scoring of internet slangs for sentiment analysis using SentiWordNet. Life Science Journal, 11(9), 66-72.

Kerswill, P. (2006). Standard English, RP and the standard-non-standard relationship. Lancaster University, 18.

Labov, W. (1969), The Logic of Nonstandard English. (Georgetown Monographs on Language and Linguistics 22) Washington, DC: Georgetown University, Center for Applied Linguistics. Reprinted in Language in the Inner City: Studies in Black English Vernacular, (1972) pp.201240. Philadelphia: University of Pennsylvania Press.

Mair, C. (2014). Globalisation and the World System of Standard and Non-standard Englishes.

Mair, C. (2016b). Digital Yaads, Cyber-Naija, and Homegirls on the Web: Using Pidgins and Creoles to Create Place in Cyberspace. Paderborn, 59.

Mair, C. (2016a). Beyond and between the "Three Circles". World Englishes research in the age of globalisation. In World Englishes: new theoretical and methodological considerations, edited by Elena Seoane and Cristina Suárez Gómez, 17-35.

Mair, C. (2017). Crisis of the "Outer Circle"?-Globalisation, the weak nation state, and the need for new taxonomies in World Englishes research. Changing English: Global and local perspectives, 5-24.

Mattiello, E. (2008). An introduction to English slang: A description of its morphology, semantics and sociology (Vol. 2, pp. 1-320). Polimetrica-International Scientific Publisher.

Melchers, G., \& Shaw, P. (2013). World Englishes (2nd ed.). London: Routledge.

McKay, S. L. (2002). Teaching English as an international language: Rethinking goals and perspectives. NY: OUP, 142-146.

McArthur, T. (2004). Is it world or international or global English, and does it matter?. English Today, 20(3), 3-15.

Ni, K., \& Wang, W. Y. (2017). Learning to explain non-standard English words and phrases. arXiv preprint arXiv:1709.09254

Partridge, E. (2015). Slang: To-day and yesterday. Routledge.

Pragasam, J. A., Singh, C. K. S., Singh, T. S. M., Mostafa, N. A., Ja'afar, H., Abdullah, M. S., ... Khaja, F. N. M. (2018). The Use of Task-Based Learning (TBL) to Improve form Four Students' Performance in Narrative Writing. International Journal of Academic Research in Progressive Education and Development, 7(3), 48-59.

Saltzman, B. A. (2017). From old English to world English.

Paige Burkette, (eds) (2017). Approaches to Teaching the History of the English Language: Pedagogy in Practice. Oxford University Press.

Migdadi, H. F., Yunus, K., \& Al.Garni, A.-F. (2020). A Global View Towards Understanding of

Standard and Non-Standard Varieties of English. International Journal of Academic Research in Business and Social Sciences, 10(2), 103-115.

Trudgill, P., \& Hannah, J. (2017). International English: A guide to varieties of English around the world. Routledge.

Trudgill, P. (1999). Standard English: what it isn't. In Bex, Tony and Watts, Richard J. (eds.) Standard English. The widening debate. London: Routledge, 
INTERNATIONAL JOURNAL OF ACADEMIC RESEARCH IN BUSINESS AND SOCIAL SCIENCES Vol. 10, No. 2, Feb, 2020, E-ISSN: 2222-6990 @ 2020 HRMARS

117-128.

Zughoul, M. R., \& Abdul-Fattah, H. (2003). Translational collocational strategies of Arab learners of English: A study in lexical semantics. Babel, 49(1), 59-81. 